University of Nebraska - Lincoln

DigitalCommons@University of Nebraska - Lincoln

1996

\title{
Multiport Well Design for Sampling of Ground Water at Closely Spaced Vertical Intervals
}

\author{
Geoffrey N. Delin \\ US Geological Survey \\ Matthew K. Landon \\ US Geological Survey
}

Follow this and additional works at: https://digitalcommons.unl.edu/usgsstaffpub

Part of the Earth Sciences Commons

Delin, Geoffrey N. and Landon, Matthew K., "Multiport Well Design for Sampling of Ground Water at Closely Spaced Vertical Intervals" (1996). USGS Staff -- Published Research. 220.

https://digitalcommons.unl.edu/usgsstaffpub/220

This Article is brought to you for free and open access by the US Geological Survey at DigitalCommons@University of Nebraska - Lincoln. It has been accepted for inclusion in USGS Staff -- Published Research by an authorized administrator of DigitalCommons@University of Nebraska - Lincoln. 


\title{
Multiport Well Design for Sampling of Ground Water at Closely Spaced Vertical Intervals
}

\author{
by Geoffrey N. Delin" and Matthew K. Landona
}

\begin{abstract}
Detailed vertical sampling is useful in aquifers where vertical mixing is limited and steep vertical gradients in chemical concentrations are expected. Samples can be collected at closely spaced vertical intervals from nested wells with short screened intervals. However, this approach may not be appropriate in all situations. An easy-to-construct and easy-to-install multiport sampling well to collect ground-water samples from closely spaced vertical intervals was developed and tested. The multiport sampling well was designed to sample ground water from surficial sand-and-gravel aquifers. The device consists of multiple stainless-steel tubes within a polyvinyl chloride (PVC) protective casing. The tubes protrude through the wall of the PVC casing at the desired sampling depths. A peristaltic pump is used to collect ground-water samples from the sampling ports. The difference in hydraulic head between any two sampling ports can be measured with a vacuum pump and a modified manometer. The usefulness and versatility of this multiport well design was demonstrated at an agricultural research site near Princeton, Minnesota where sampling ports were installed to a maximum depth of about $\mathbf{1 2} \mathbf{~ m}$ below land surface. Tracer experiments were conducted using potassium bromide to document the degree to which short-circuiting occurred between sampling ports. Samples were successfully collected for analysis of major cations and anions, nutrients, selected herbicides, isotopes, dissolved gases, and chlorofluorcarbon concentrations.
\end{abstract}

\section{Introduction}

The importance of sampling ground water at closely spaced vertical intervals near the water table has been demonstrated in numerous investigations of ground-water contamination from point and nonpoint sources (Egboka, 1985; Dorr et al., 1987; Ronen et al., 1987; Margaritz et al., 1989; Bottcher et al., 1990; Gibs and Imbrigiotta, 1990; LeBlanc et al., 1991; Rea et al., 1991; Smith et al., 1991; Gibs et al., 1993; Landon et al., in press). Detailed vertical sampling is needed in aquifers where vertical mixing is limited and there are steep vertical gradients in chemical concentration. The concentrations of many chemical constituents, such as nitrate-nitrogen $\left(\mathrm{NO}_{3}-\mathrm{N}\right)$, may vary significantly over short vertical distances, particularly in the upper few meters of the saturated zone (Bottcher et al., 1990; Smith et al., 1991; Landon et al., in press). Therefore, detailed vertical sampling provides the number of samples necessary to fully define the local geochemical processes. Water samples collected from conventional wells represent an integration across the entire screened interval. The chemistry and flow rate of water that

U.S. Geological Survey, 2280 Woodale Drive, Mounds View, Minnesota 55112.

Received May 1995, revised November 1995, accepted January 1996 enters the well screen can be variable and is dependent on aquifer hydraulic properties (Gibs et al,, 1993). A nest of wells with short screened intervals can be used to collect samples from closely spaced vertical intervals. However, expenses for drilling and materials using this approach can be excessive (Gillham et al., 1983). In addition, it may be difficult or impractical to install a well nest, over a horizontal distance of several meters, where measurements of chemical concentrations are required from closely spaced vertical intervals within a single borehole. The American Society for Testing and Materials (1990) recommends that the vertical spacing between nested wells with screen lengths of $0.3 \mathrm{~m}$ be no less than $0.9 \mathrm{~m}$. Therefore, there is a growing need for single-hole multilevel sampling devices for both contaminant and ground-water resource studies.

Several designs for multilevel or multiport wells have been used to sample ground water from closely spaced vertical intervals in single boreholes (Cherry et al., 1983). One system that uses dialysis cells (Ronen et al., 1986) has been successful, but the volume of water that can be collected from each sampling depth is limited by the diameter of the well casing. In addition, water collected with dialysis (diffusion) cells represents a timeintegrated sample that may not be coincidental with the period of interest. Multilevel samplers that have multiple sampling points within a well screen (Gibs et al., 1993; Hansen and Harris, 1980) are effective but may be susceptible to cross contamination between sampling levels. 
This paper describes a multiport well (herein referred to as a multiport) that can be used to collect ground-water samples from sand and gravel aquifers at closely spaced vertical intervals. This paper also describes the procedures for installing the multiport and the procedures for sample collection using the multiport. Results of field tracer experiments designed to test for shortcircuiting between sampling ports are also presented. Data are presented from a site near Princeton in east-central Minnesota, to illustrate the type of results that can be obtained when the multiport is installed in a sand-and-gravel aquifer.

\section{Construction of the Multiport Well}

The multiport has a simple design, can be easily constructed in the field, and is easy to install (Figure 1). The multiports are constructed using readily available, nonreactive materials such as stainless-steel tubing. The appropriate diameter of the sampling ports and the spacing between the sampling ports are governed by the required pumping rate and by the hydrogeologic characteristics of the research site. The multiport is similar to the designs of Pickens et al. (1978) and Wells (1988). However, the device described by Pickens et al. includes materials such as rubber that could adsorb or react with some organic chemicals, whereas the multiport is constructed of primarily nonreactive materials. Construction of the sampling tubes also is different in the two designs. The device described by Wells utilizes factorymilled screens, whereas the multiport can be constructed and customized in the field.

A detailed description of the multiport well is as follows. Each multiport consists of an outer protective casing constructed of $5.1-\mathrm{cm}$ inside diameter (i.d.), schedule-80 polyvinyl chloride (PVC) (Figure 1). Holes of about $0.7-\mathrm{cm}$ diameter were drilled at about a 45-degree angle through the side of the PVC casing at the desired sampling depths. Spacing between sampling ports was determined by first estimating the volume of water withdrawn during sampling from within a sphere of aquifer surrounding an individual port. Each sampling port was separated from adjacent ports by a minimum of about two times the radial distance of this sphere. The assumptions used in making this estimate were that aquifer porosity is 0.3 and that about 101 of water would be pumped from a uniform sphere of aquifer material during sampling. A spacing of $0.5 \mathrm{~m}$ was used in the upper $2 \mathrm{~m}$ of the saturated zone and a spacing of $2 \mathrm{~m}$ was used at greater depths.

Stainless-steel sampling tubes $[0.64-\mathrm{cm}$ outside diameter (o.d.), 0.53-cm i.d.] were inserted from outside the casing through the $0.7 \mathrm{~cm}$ holes until about $10 \mathrm{~cm}$ was left protruding outside the PVC casing. Six $0.64-\mathrm{cm}$ o.d. stainless-steel tubes can fit inside the $5.1-\mathrm{cm}$ i.d. PVC casing. The top of each tube was numbered consecutively, from shallowest to deepest, using stickon labels at the time of installation. A screened interval was created by cutting slots in the lower part of the tubing with a Dremel tool. (Use of brand names in this report is for identification purposes only and does not constitute endorsement by the U.S. Geological Survey.) Slots were cut into about a $2.5-\mathrm{cm}$ length of the tubing for the multiports used at the Princeton site. The bottom of each tube was then crimped shut. It is recommended that all metal shavings and Dremel tool cutting-wheel debris be removed with compressed air prior to crimping the tubes shut. A piece of 100-mesh stainless-steel screen was secured over the slots with stainless-steel wire (Figure 1), and a stainless-steel hose clamp was used to fasten the end of the sampling tube to the casing. It is recommended that marine grade hose clamps be used; the steel screws typically used in automotive grade hose clamps will rust in time, affecting the water chemistry and allowing the clamp to loosen. Silicone caulk was used to seal the annulus between the stainless-steel tubing and the hole drilled in the PVC casing to prevent water from entering the casing. The silicone caulk used in this design was deemed suitable for evaluating the effects of agricultural chemicals on groundwater quality. A different, more nonreactive sealant would be more appropriate, however, when using the multiport design to sample for volatile organic chemicals.

Materials to construct a multiport measuring $5 \mathrm{~m}$ in length with 6 ports cost about $\$ 225$, based on 1994 prices. By comparison, materials for a corresponding nest of six wells constructed of $5.1-\mathrm{cm}$ i.d. galvanized-steel casing and stainless-steel screens cost about $\$ 600$. Although these costs may not be reflective of prices in all locations, they should be an accurate reflection of the relative costs for construction materials for the two types of well installations and demonstrate a clear cost advantage of this design over the cost of a conventional well nest. These comparative cost estimates do not include costs for drilling or labor. Drilling and labor costs likely would be greater to install six wells, which would further increase the savings of the multiport design over conventional methods.

\section{Installation of the Multiport Well}

Each multiport was easily installed in a sand-and-gravel aquifer using the procedures described in the following paragraph. These procedures may need to be modified when installing the multiport in materials having lower hydraulic conductivities, such as glacial till.

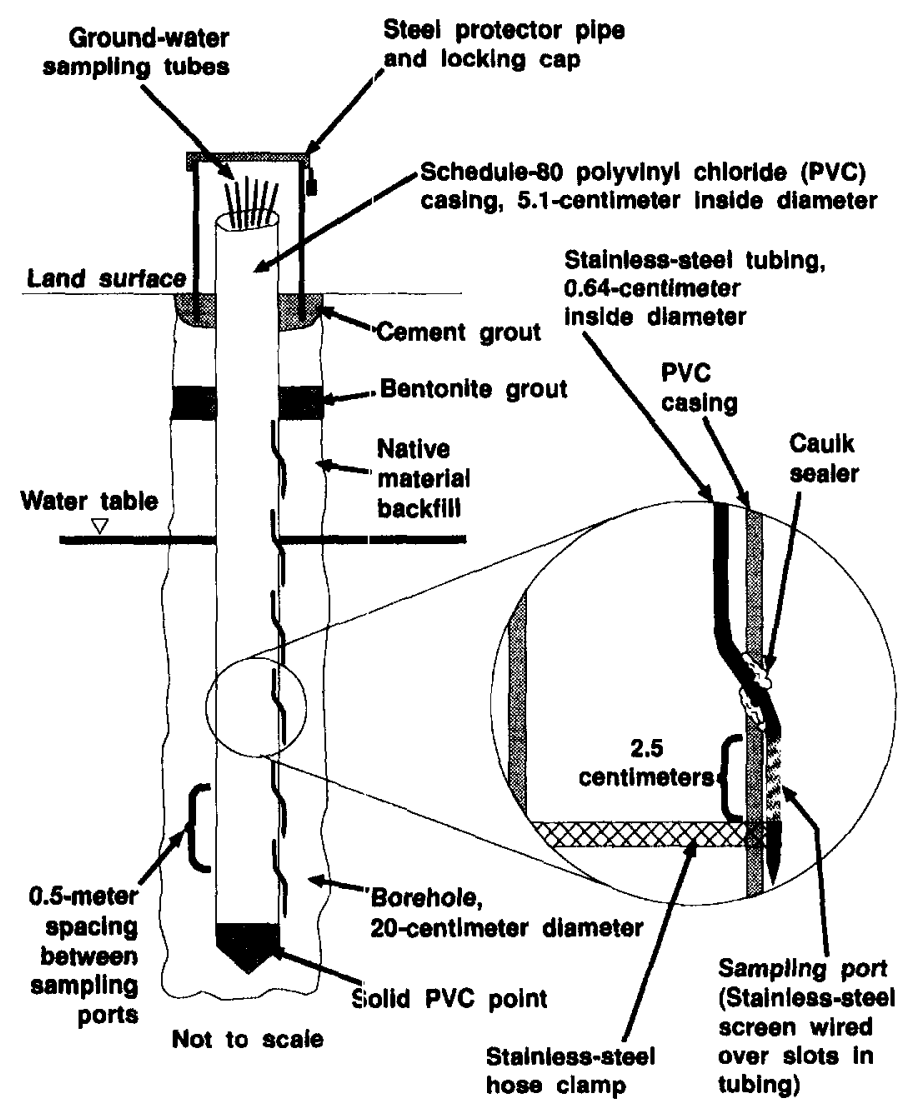

Fig. 1. Schematic diagram of multiport well. 
Each multiport was installed through the annulus of 10.2-cm i.d. hollow-stem auger. A PVC plate was first inserted in the end of the augers to prevent sand from being forced inside the bottom of the augers during the drilling process. The augers were also filled with water to create a positive hydraulic head, relative to the head in the aquifer, to minimize the likelihood of sand being forced inside the bottom of the augers. Drilling continued to the depth where the deepest sampling port was to be installed. The multiport was then used to force the PVC plate off the end of the augers, taking adequate precautions to avoid damaging the multiport. The augers were then removed and the natural formation collapsed around the multiport below the water table. Native material or a sand pack was then added to the annular space of the augered hole from the water table to land surface, with the exception of a one-meter thick layer of bentonite in the unsaturated zone and a one-meter thick layer of cement installed at the surface. The multiports were successfully installed to a maximum depth of about $12 \mathrm{~m}$ below land surface at the Princeton site. Following installation, the screened interval of each sampling port was developed by pumping with a peristaltic pump to remove fine particles in the screen and the surrounding aquifer.

\section{Field Tracer Experiments}

A concern with this multiport design was that ground water would move preferentially along the casing between the sampling ports. This "short-circuiting" could occur along the inside of the casing if water entered through the holes drilled in the casing or along the outside of the casing through the disturbed native material. Therefore, tracer experiments were conducted to document the degree to which short-circuiting occurred between sampling ports.

The tracer experiments were conducted between sampling ports spaced $0.5 \mathrm{~m}$ apart. Potassium bromide was used as a tracer because it moves conservatively with water (Davis et al., 1980). The experimental procedure was to (1) inject with a peristaltic pump about $250 \mathrm{ml}$ of potassium bromide solution with a concentration of about $1,000 \mathrm{mg} / \mathrm{l}$ into one of the sampling tubes, (2) immediately inject about $100 \mathrm{ml}$ of deionized water into the sampling tube to flush the potassium bromide out the end of the sampling port, (3) continuously pump water from the overlying sampling port at a rate of about $1 \mathrm{l} / \mathrm{min}$, (4) measure and plot specific conductance and bromide concentrations in this sample water until a breakthrough curve developed, and (5) pump water out of both the injection and withdrawal ports until the specific conductance reached background concentrations. This experimental procedure then was repeated by pumping from the port underneath the injection port. The $11 / \mathrm{min}$ pumping rate was used to replicate the actual pumping rate used in collecting ground-water samples at the Princeton site. Bromide samples were analyzed with an ion-specific electrode about every 10 minutes and specific conductance was monitored continuously, as an indication of changes in bromide concentration.

Two sets of tracer experiments were conducted; one immediately after the first multiport was installed and a second about one year later, after the ports had been sampled several times. Tests were conducted on several different multiports. During the experiment just after installation of the first multiport, the first breakthrough of potassium bromide was detected in the overlying sampling port about 60 minutes after injection. This time lag was considered acceptable because the total sampling time for each port during actual operations was less than 15 minutes. During tests completed one year after the multiports were installed, potassium bromide was not detected in the overlying or underlying ports after 200 minutes of pumping. These results indicate that water pumped from the sampling ports originated in the aquifer adjacent to the port and that there was not rapid vertical movement (short-circuiting) of water between sampling ports. Thus, the native aquifer material created a relatively continuous flow regime around the multiport and the design is an effective method for collecting ground-water samples at closely spaced vertical intervals in sand-and-gravel aquifers.

\section{Water Sampling}

Sampling of the multiports is accomplished with a suctionlift (vacuum) pump. Thus, water sampling using the multiport design can be achieved in areas where the water level is less than the maximum suction-lift depth of about $9 \mathrm{~m}$ below land surface (Cherry et al., 1983).

At the Princeton site, ground-water samples were collected by connecting a peristaltic pump to the stainless-steel tubes at the top of the multiports. Teflon tubing was used in the pumping system, except for approximately $10 \mathrm{~cm}$ of silicone tubing in the peristaltic pump head and an approximately $4-\mathrm{cm}$ long piece of silicone tubing used to attach the Teflon tubing to the stainlesssteel sampling tubes of the multiports. The typical pumping rate ranged from $0.8-1.0 \mathrm{l} / \mathrm{min}$. Previous investigations have recommended that samples be collected after stable values are achieved for dissolved oxygen, $\mathrm{pH}$, temperature, and specific conductance, which typically occurs after a minimum of three well volumes are purged (Wood, 1981; Classen, 1982; Gibs and Imbrigiotta, 1990). Because each sampling tube contains a very small volume of water, typically less than $0.1 \mathrm{l}$, purging of three well volumes was completed less than one minute after pumping began. To reduce the possibility of inducing significant vertical movement of ground water between sampling ports, the total pumping time for each multiport was kept to the minimum time necessary for the field parameters to stabilize (usually about 8 minutes) and to fill the necessary sample bottles. Total pumping time for each sampling port usually was less than 15 minutes.

\section{Measurement of Difference in Hydraulic Head}

The difference in hydraulic head between any two sampling ports can be measured using a vacuum pump and the modified manometer shown in Figure 2, similar to a design presented by Winter et al. (1988). The device consists of a head-measurement platform (A) mounted on a tripod. The base of the head-measurement platform can be made of aluminum or other suitable material. Two transparent tubes $(B)$, with a maximum i.d. of $0.6 \mathrm{~cm}$, and two rulers $(C)$ are mounted onto the front of the board. Transparent tubing smaller than $0.06-\mathrm{cm}$ i.d. is preferable, particularly if the difference in head is small, to amplify the differences in head between the sampling ports being measured. The top ends of the transparent tubes are brought together in a union (E) using pressure fittings (D) and stainless-steel tubing (F). Teflon tubing (I) is connected between the union and a vacuum tank. A filtering (Erlenmeyer) flask $(H)$ should be inserted between the head-measurement platform and the vacuum tank to catch any water that accidentally is drawn past the rulers. A length of Teflon tube $(J)$ is connected to the bottom end of each transparent tube. A small level should be mounted on the head-measurement platform to ensure that the two rulers are at the same elevation. 


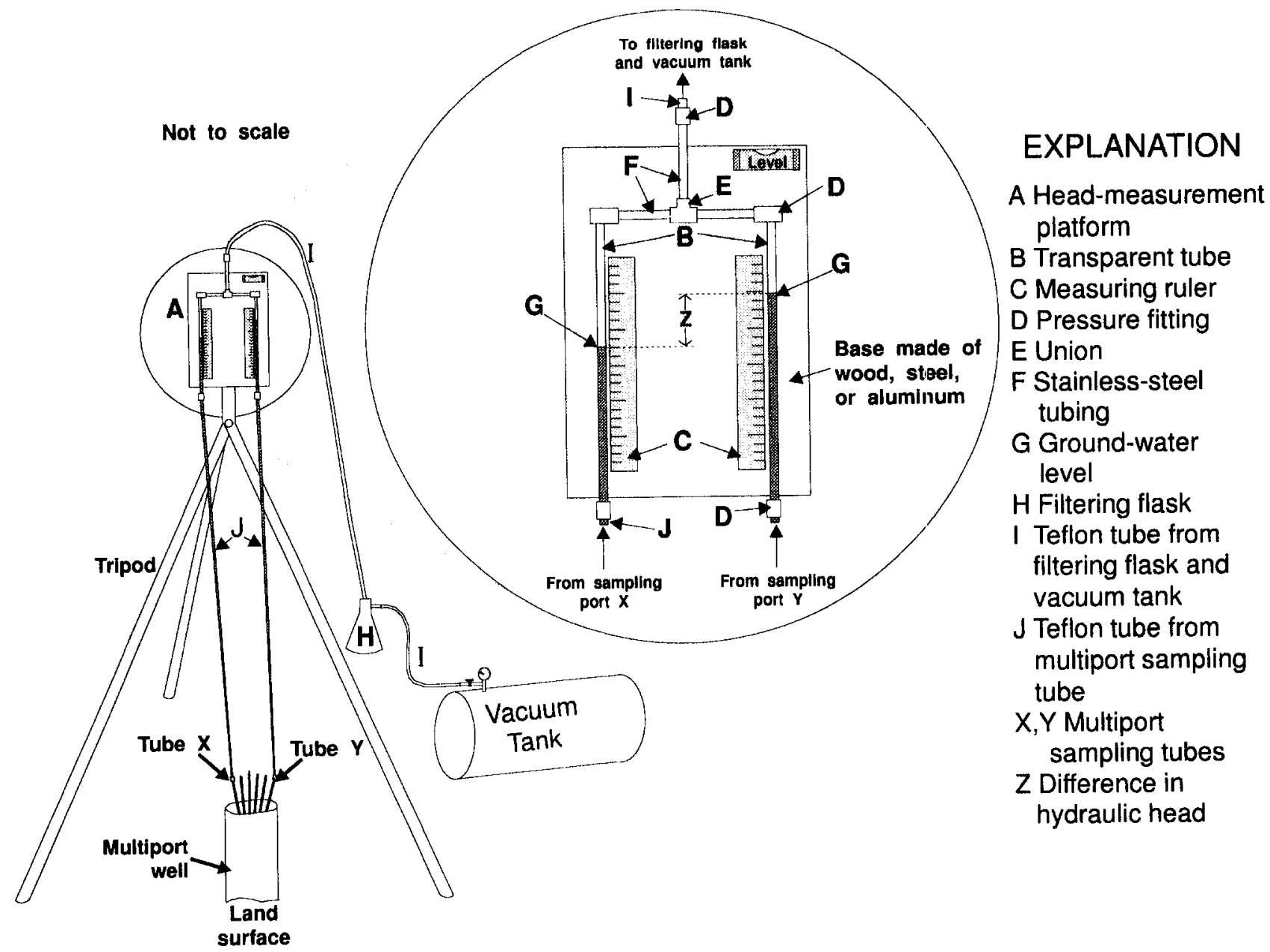

Fig. 2. Schematic diagram of manometer apparatus used to measure differences in hydraulic head in a multiport well.

To measure the hydraulic head between two sampling ports, Teflon tubes $(\mathrm{J})$ are connected to any two multiport sampling tubes ( $\mathrm{X}$ and $\mathrm{Y}$, Figure 2). A vacuum is gradually applied to both sampling tubes, drawing water from the two sampling depths into the transparent tubes adjacent to the measuring sticks. The vacuum is turned off as soon as both water levels are within the measuring range and the water levels are allowed to equilibrate. Because the same vacuum is applied to both sampling tubes, the observed difference in the water levels results from the difference in hydraulic head between the sampling ports. The water-level elevation is noted on each ruler, and the difference in hydraulic head $(Z)$ between the two sampling ports is calculated (Figure 2). By alternately measuring the various combinations of sampling ports in a given multiport, the relative differences between all sampling ports can be determined. The absolute head could also be measured in each multiport tube by using a slim (less than $0.5-\mathrm{cm}$ o.d.) cable or water-level measuring tape.

\section{Results}

The multiport was used in a sampling program near Princeton, Minnesota to evaluate how ground-water quality was affected by experimental farming practices (Landon et al., in press). The multiport was used to obtain water samples for analyses of major cations and anions, nutrients, selected herbicides, isotopes, and dissolved gases. The multiport was also used to collect samples for ground-water age dating using chlorofluorcarbon techniques.
Twenty-two multiports were installed at the Princeton site (Delin et al., 1994). The site is in a glacial outwash aquifer that consists of medium-to-coarse sand to fine gravel (Delin et al., 1994). The saturated and unsaturated zones contain medium-tocoarse sand and fine gravel with discontinuous layers of silty sand up to $20 \mathrm{~cm}$ thick. A predominantly clayey till underlies the surficial aquifer. The average saturated hydraulic conductivity of the aquifer is about $0.04 \mathrm{~cm}$ per second. Ground-water recharge rates generally range from 10 to $20 \mathrm{~cm}$ per year. During 199192, when the multiports were installed, the average depth to the water table was $3.6 \mathrm{~m}$ and the saturated thickness ranged from 4 to $16 \mathrm{~m}$. The water table fluctuated seasonally from 0.3 to $1.0 \mathrm{~m}$. This type of hydrogeologic setting is common throughout the midwest corn belt and is susceptible to ground-water contamination.

Concentrations of selected chemical constituents at the Princeton site as a function of depth are shown in Figure 3 to illustrate how this multiport design was useful in detecting vertical changes in concentration gradients. Each of the vertical profiles represent data collected from a multiport installed in the upper $2 \mathrm{~m}$ of the saturated zone and another adjacent multiport, with ports located $3-8 \mathrm{~m}$ below the water table. Fluctuations in $\mathrm{SO}_{4}$ concentrations over short vertical distances were detected with the multiport configuration (Figure $3 \mathrm{~A}$ ). Concentrations of $\mathrm{NO}_{3}-\mathrm{N}$ and dissolved oxygen decreased from greater than $20 \mathrm{mg} / \mathrm{l}$ and greater than $8 \mathrm{mg} / \mathrm{l}$, respectively, near the water table to less than $0.5 \mathrm{mg} / \mathrm{l}$ at a depth of $6 \mathrm{~m}$ below the water 
table. The rapid decrease in $\mathrm{NO}_{3}-\mathrm{N}$ and dissolved-oxygen concentrations in the upper $2 \mathrm{~m}$ of the saturated zone was distinctly identified with the $0.5-\mathrm{m}$ spacing between the ports. Thus, use of the multiports facilitated identification of a boundary between oxidized and reduced ground water between 4 and $6 \mathrm{~m}$ below the water table, which is consistent with the occurrence of denitrification.

Use of the multiports allowed detection of vertical variations in the concentrations of atrazine metabolite de-ethylatrazine from about $0.03 \mu \mathrm{g} / \mathrm{l}$ near the water table to about $0.20 \mu \mathrm{g} / \mathrm{l} 3 \mathrm{~m}$ below the water table (Figure 3B). Atrazine concentrations were generally at trace concentrations, between the detection limit of $0.01 \mu \mathrm{g} / \mathrm{l}$ and the reporting limit of $0.04 \mu \mathrm{g} / \mathrm{l}$. Concentrations of chemical constituents in the multiports generally agreed within about 20 percent of the concentrations in nearby nested wells with $15-\mathrm{cm}$ long screened intervals at the same depths.

The modified manometer apparatus described above was used to measure head differences in selected multiports installed at the Princeton site. The head differences across the 2-m thickness of saturated zone instrumented with the multiports were typically less than $0.2 \mathrm{~cm}$. This value compares favorably with the head differences across the $14-\mathrm{m}$ saturated thickness of the aquifer, of $0.05-0.2 \mathrm{~cm}$ measured in conventional wells.

\section{Discussion}

The versatility of the multiport design allows for variations in design, materials, and construction methods. Materials such as Teflon, polyethylene, or polypropylene tubing, for example, could be used in place of the stainless-steel tubing. Barcelona et al. (1983) recommend materials such as stainless steel or Teflon, however, when sampling for trace concentrations of organic compounds. Fiberglass or a different type of sealer could be used in place of the silicone caulk. Nylon fabric could be used as screen material over the slotted tubing instead of a stainless-steel screen (Pickens et al., 1978). The appropriate

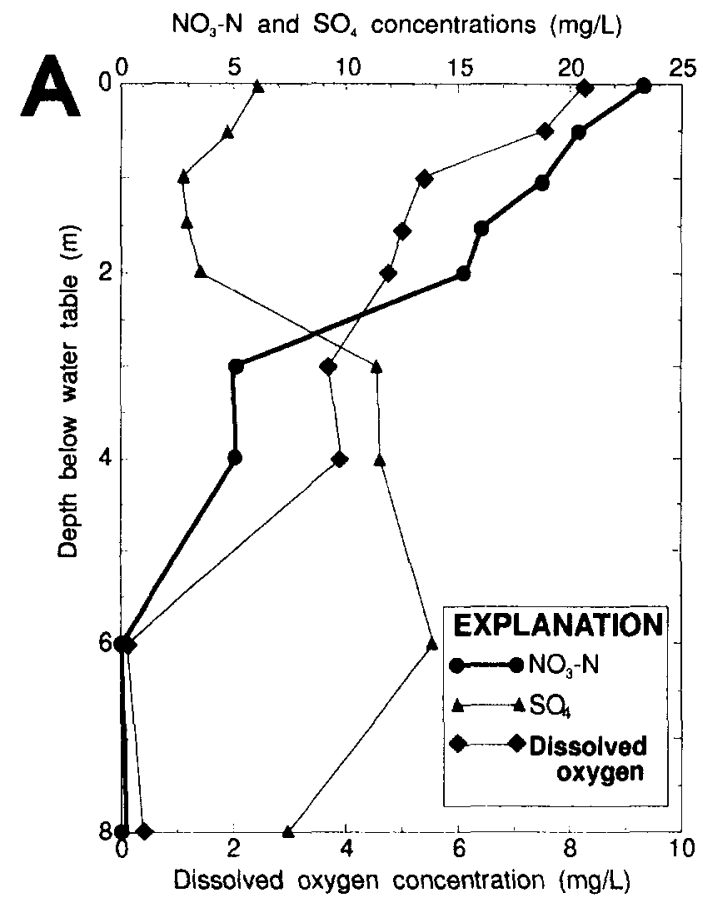

length of the screened interval depends on the hydraulic properties of the porous material in which the multiport is installed and on the required pumping rate. Screened intervals longer than $3 \mathrm{~cm}$ could be used to increase potential pumping rates. Spacing of less than $0.5 \mathrm{~m}$ between the sampling ports would yield greater resolution of vertical changes in chemical concentrations. More than six sampling tubes of $0.64-\mathrm{cm}$ o.d. could be installed if a PVC protective casing larger than $5.1-\mathrm{cm}$ i.d. were used (e.g., 7.6-cm i.d.). Larger diameter sampling tubes (e.g., $1.3-\mathrm{cm}$ i.d.) could be installed in the PVC protective casing, thus allowing for a greater pumping rate compared to the $0.64-\mathrm{cm}$ o.d. sampling tubes used at the Princeton site. A modification of the sampling design is to connect all of the sampling tubes to a multihead pump to facilitate simultaneous pumping of all ports.

An alternative installation method is to drill to the desired depth using a pilot bit, instead of the PVC plate. The pilot bit is removed and any sand that heaved into the annuluses of the augers could be washed out before installing the multiport. Another possible modification is the emplacement of bentonite, or other low permeability material, between each sampling port as a barrier to vertical ground-water movement through the borehole. Alternating layers of sand and bentonite could then be installed inside the hollow-stem augers as the augers were removed from the test hole, thus isolating each sampling port.

The multiport design could be used to evaluate water quality and ground-water movement in fractured-rock formations as an alternative to formation packers. Sampling ports could be located adjacent to individual fractures and sand-packed in place. A layer of bentonite could then be used to hydraulically isolate each sampling port. Water samples could be collected to evaluate vertical changes of chemical concentrations in the fractured system. Hydraulic-head measurements in the multiports could be used to evaluate changes in head within a single borehole or to evaluate fracture continuity between similarly instrumented boreholes.

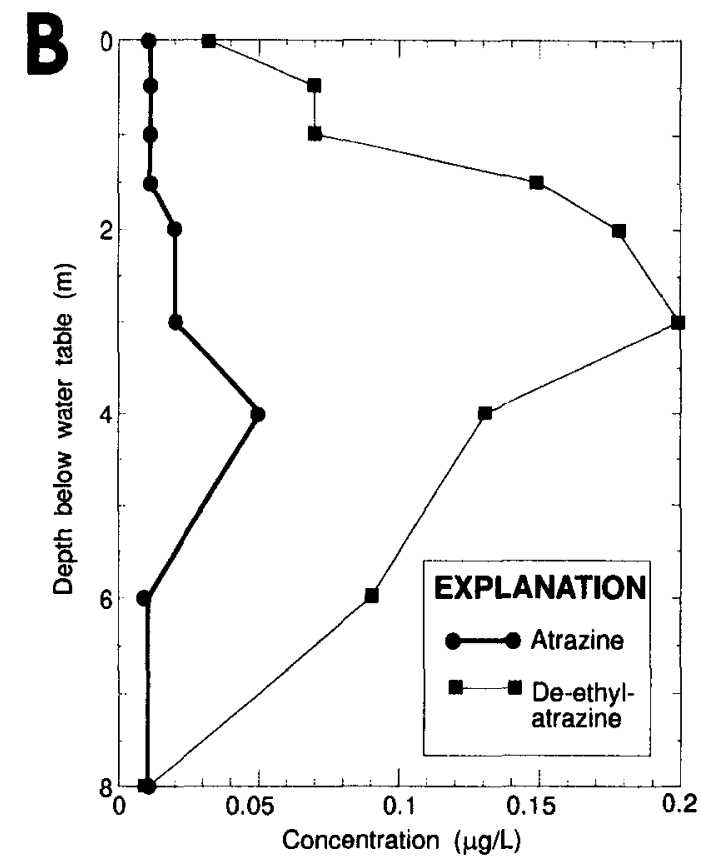

Fig. 3. Typical changes in the concentrations of selected chemical constituents in multiport wells at Princeton, Minnesota, 1992-93. (A) inorganic constituents; (B) atrazine and de-ethylatrazine. 
The multiport design could also be used for sampling vapors in the unsaturated zone. For this purpose, the ports simply need to be installed in the unsaturated zone above the water table. A vacuum pump, or other sampling device, could then be connected to the sampling tubes similar to the configuration used to sample water. Ports could be placed both above and below the water table to sample both vapor and water with the same multiport well. Vapor-phase sampling with the multiports could prove extremely useful for evaluating the effects of ground-water contamination from volatile organic compounds, such as those associated with gasoline contamination. Barker et al. (1987) discuss some biases in sampling multilevel devices for volatile organics.

Although the multiport design has numerous advantages over conventional nested monitoring well networks, several disadvantages are apparent. Sampling of the multiports can only be made with a suction-lift pump, which limits use of the design to areas where the water level is less than the maximum suctionlift depth of about $9 \mathrm{~m}$ below land surface. Degassing of dissolved gases occurs because of this suction-lift pumping. The relatively small tube diameter, compared to conventional wells, also limits the pumping rate. Without modification, the multiports do not yield much water when completed in clay-rich or silty soils, based on results at Princeton (Delin et al., 1994) and elsewhere in Minnesota (S.C. Komor, U.S. Geological Survey, written commun., 1995). Collapse of the aquifer sediments around the multiport well potentially changes, and presumably increases, the hydraulic conductivity of the aquifer in the disturbed area. Shortcircuiting between sampling ports may occur in ground-water flow systems where smaller hydraulic conductivities are present because the material is less likely to collapse. In some instances, this short-circuiting can be overcome by installing a bentonite seal between the individual sampling ports. An alternative method would be to attach a nylon mesh filled with bentonite pellets around the casing between each sampling port.

The stainless-steel tubes are supported primarily by the hose clamp (Figure 1) and press down directly on the silicone seal. Over time, the sealant could shift causing the water-tight seal to fail, resulting in a potential pathway for chemical and hydraulic communication between the sampling ports. The design could be modified to address this concern by similarly clamping the tubes to the casing at land surface, thereby minimizing downward pressure on the sealant and preserving the seal made by the silicone. Clamping of the tubes to the casing would also eliminate their movement at land surface, which could also adversely affect the silicone seal over time.

\section{Summary and Conclusions}

This multiport design provides a means for collecting water samples from surficial aquifers at closely spaced vertical intervals. Advantages of the multiport design include relatively small construction costs compared to conventional nested wells. The design allows for flexibility in the use of construction materials, including materials recommended for sampling of organic chemicals. The design permits use of variable screen lengths and tubing diameters. The multiport is rapidly and easily assembled in the field to meet various sampling requirements. The multiport design allows for collection of ground-water quality samples that represent a smaller volume of aquifer compared to the integrated sample obtained from a conventional well screen. Less time is required to purge water prior to sampling the multiports compared to conventional wells. Thus, water samples are in contact with the sampling equipment for a shorter period of time compared to conventional sampling systems. Differences in hydraulic head can be made at closely spaced vertical intervals with the multiport design and the head-measurement apparatus described herein. This multiport design could be used in fractured-rock systems and for vapor-phase sampling in the unsaturated zone. Overall, the device is easy to construct with readily available materials and is easy to install.

\section{Acknowledgments}

Research, conducted when this multiport was designed, was funded by the U.S. Geological Survey Toxic Substances Hydrology Program. The authors would like to thank M.F. Hult, formerly of the U.S. Geological Survey, for technical assistance and ideas that were instrumental in developing the multiport. The authors would also like to thank J.S. McLean, formerly of the U.S. Geological Survey, for technical assistance and ideas helpful in designing the apparatus used to measure differences in hydraulic head through the multiport. The assistance of D.L. Rosemore of the U.S. Geological Survey is appreciated in the design and field testing of the head-measurement apparatus. The authors are grateful to the Minnesota Pollution Control Agency, University of Minnesota-Soil Science Department, and the U.S. Department of Agriculture-Agricultural Research Service who were cooperators in the research at the Princeton site.

\section{References}

American Society of Testing and Materials. 1990. Standard practice for design and installation of ground water monitoring wells in aquifers. American Society for Testing and Materials, Standard D5092-90, Philadelphia, PA. 12 pp.

Barcelona, M.J., J.P. Gibb, and R.A. Miller. 1983. A guide to the selection of materials for monitoring well construction and ground-water sampling. Illinois State Water Survey Contract Report 327, Champaign, IL. $78 \mathrm{pp}$.

Barker, J.F., G.C. Patrick, L. Lemon, and G.M. Travis. 1987. Some biases in sampling multilevel piezometers for volatile organics. Ground Water Monitoring Review. v. 7, no. 2, pp. 48-54.

Bottcher, J., O. Strebel, S. Voerkelius, and H.L. Schmidt. 1990. Using isotope fractionation of nitrate-nitrogen and nitrate-oxygen for evaluation of microbial denitrification in a sandy aquifer: Journal of Hydrology. v. 114, no. 3/4, pp. 413-424.

Cherry, J.A., R.W. Gillham, E.G. Anderson, and P.E. Johnson. 1983. Migration of contaminants in groundwater at a landfill; a case study, groundwater monitoring devices. Journal of Hydrology. v. 63 , no. $1-2$, pp. $31-49$.

Classen, H.C. 1982. Guidelines and techniques for obtaining water samples that accurately represent the water chemistry of an aquifer. U.S. Geological Survey Open-file Report 82-1024. 49 pp.

Davis, S.N., G.M. Thompson, H.W. Bentley, and G. Stiles. 1980. Ground-water tracers-A short review. Ground Water. v. 18, no. 1, pp. 14-23.

Delin, G.N., M.K. Landon, J.A. Lamb, and J.L. Anderson. 1994. Characterization of the hydrogeology and water quality at the Management Systems Evaluation Area near Princeton, Minnesota. U.S. Geological Survey Water-Resources Investigations Report 94$4149.54 \mathrm{pp}$

Dorr, H., C. Sonntag, and W. Regenberg. 1987. Field study on the initial C-14 content as a limiting factor in C-14 groundwater dating. In: Isotope Techniques in Water Resources Development, Proceedings of an International Symposium, Vienna, Austria, April 3, 1987. pp. 73-86.

Egboka, B.C.E. 1985. Appropriate monitoring techniques using bomb tritium and other geochemical parameters in hydrogeological investigations. Hydrological Sciences Journal. v. 30, no. 2, pp. 207-224

Gibs, Jacob and T.E. Imbrigiotta. 1990. Well-purging criteria for sam- 
pling purgeable organic compounds. Ground Water. v. 28 , no. 1, pp. 68-77.

Gibs, Jacob, G.A. Brown, K.S. Turner, C.L. MacLeod, J.C. Jelinski, and S.A. Koehnlen. 1993. Effects of small-scale vertical variations in well-screen inflow rates and concentrations of organic compounds on the collection of representative ground-waterquality samples. Ground Water. v. 31, no. 2., pp. 201-208.

Gibs, Jacob, G.A. Brown, and K.S. Turner. 1991. Use of a multilevel sampler to determine vertical concentration gradients of volatile aromatic hydrocarbons in ground water, Galloway Township, New Jersey, In: U.S. Geological Survey Toxic Substances Hydrology Program - Proceedings of the Technical Meeting, Monterey, CA, March 11-15, 1991. Water-Resources Investigations Report 91-4034. pp. 268-275.

Gillham, R.W., M.J.L. Robin, J.F. Barker, and J.A. Cherry. 1983. Ground water sampling bias. American Petroleum Institute, American Petroleum Institute Publication 4367, Washington, DC. June 1983, 206 pp.

Gilmore, T.J. 1989. Installation of the Westbay multiport ground water sampling system in well $699-43-42 \mathrm{~K}$ near the $216-\mathrm{b}-3$ pond. Pacific Northwest Laboratories Report no. PNL-6973. 28 pp.

Hansen, E.A. and A.R. Harris. 1980. An improved technique for spatial sampling of solutes in shallow groundwater systems. Water Resources Research. v. 16, no. 4, pp. 827-829.

Landon, M.K., G.N. Delin, J.A. Lamb, R.H. Dowdy, and J.L. Anderson. In press. Effects of farming systems on ground-water quality at the Princeton, Minnesota Management Systems Evaluation Area, 1991. In: Morganwalp, D.W. and D.A. Aronson, eds. U.S. Geological Survey Toxic Substances Hydrology Program-Proceedings of the Technical Meeting, Colorado Springs, CO, September 2024, 1993. U.S. Geological Survey Water Resources Investigations Report 94-4015. $12 \mathrm{pp}$.

Le Blanc, D.R., S.P. Garabedian, K.M. Hess, L.W. Gelhar, R.D. Quadri, K.G. Stollenwerk, and W.W. Wood. 1991. Large-scale natural gradient tracer tests in sand and gravel, Cape Cod, Massachusetts-Experimental design and observed tracer movement. Water Resources Research. v. 27, no. 5. pp 895-910.
Margaritz, M., W. Mona, A.J. Amiel, and D. Ronen. 1989. Application of a multi-layer sampler based on the dialysis cell technique for the study of trace metals in groundwater. Applied Geochemistry. v. 4 , pp. $617-624$.

Pickens, J.F, J.A. Cherry, G.E. Grisak, W.F. Merrit, and B.A. Risto. 1978. A multilevel device for ground-water sampling and piezometric monitoring. Ground Water. v. 16, no. 5, pp. 322-327.

Rea, B.A., D.B. Kent, D.R. LeBlanc, and J.A. Davis. 1991. Mobility of zinc in a sewage-contaminated aquifer, Cape Cod, Massachusetts. In: U.S. Geological Survey Toxic Substances Hydrology Program-Proceedings of the Technical Meeting, Monterey, CA. March 11-15, 1991. Water-Resources Investigations Report 914034. pp. 87-94.

Ronen, D., M. Magaritz, and I. Levy. 1986. A multi-layer sampler for the study of detailed hydrochemical profiles in groundwater. Water Resources Research. v. 20, pp. 311-315.

Ronen, D., M. Magaritz, H. Gvirtzman, and W. Garner. 1987. Microscale chemical heterogeneity in ground water. Journal of Hydrology. v. 92, pp. 173-178.

Smith, R.L., R.W. Harvey, and D.R. LeBlanc. 1991. Importance of closely spaced vertical sampling in delineating chemical and microbiological gradients in ground water studies. Journal of Contaminant Hydrology. v. 7, no. 3, pp. 285-300.

Wells, C.E. 1988. Design and installation of a simple, cost effective, multi-level monitoring well system. In: Proceedings of the Second National Outdoor Action Conference on Aquifer Restoration, Ground Water Monitoring and Geophysical Methods, National Water Well Assoc., Dublin, OH. v. I, pp. 415-433.

Winter, T.C., J.W. LaBaugh, and D.O. Rosenberry. 1988. Geological Survey design of a hydraulic potentiomanometer for direct measurement of differences in hydraulic head between ground water and surface water. Limnology and Oceanography LIOCAH. v. 33 , no. 5 , pp. $1209-1214$.

Wood, W.W. 1981. Guidelines for collection and field analysis of groundwater samples for selected unstable constituents. U.S. Geological Survey Techniques of Water-Resources Investigations. Book 1 , Chap. D2, 24 pp. 